Research Article

\title{
Catalytic Pyrolysis of Municipal Solid Waste: Effects of Pyrolysis Parameters
}

\author{
Hamad Almohamadi1,", Abdulrahman Aljabri'2, Essam R.I. Mahmoud ${ }^{2}$, Sohaib Z. Khan², \\ Meshal S. Aljohani ${ }^{3}$, Rashid Shamsuddin ${ }^{4}$
}

${ }^{1}$ Department of Chemical Engineering, Faculty of Engineering, Islamic University of Madinah, Madinah, Saudi Arabia

${ }^{2}$ Department of Mechanical Engineering, Faculty of Engineering, Islamic University of Madinah, Madinah, Saudi Arabia.

${ }^{3}$ King Abdulaziz City for Science and Technology (KACST), P.O. Box 6086, Riyadh 11442,

Saudi Arabia.

${ }^{4}$ Department of Chemical Engineering, Universiti Teknologi PETRONAS, 326107 Bandar Seri Iskandar, Perak

Darul Ridzuan, Malaysia.

Received: $2^{\text {nd }}$ March 2021; Revised: 17th March 2021; Accepted: 17th March 2021

Available online: 18 ${ }^{\text {th }}$ March 2021; Published regularly: June 2021

Abstract

Burning municipal solid waste (MSW) increases $\mathrm{CO}_{2}, \mathrm{CH}_{4}$, and $\mathrm{SO}_{2}$ emissions, leading to an increase in global warming, encouraging governments and researchers to search for alternatives. The pyrolysis process converts MSW to oil, gas, and char. This study investigated catalytic and noncatalytic pyrolysis of MSW to produce oil using $\mathrm{MgO}$-based catalysts. The reaction temperature, catalyst loading, and catalyst support were evaluated. Magnesium oxide was supported on active carbon (AC) and $\mathrm{Al}_{2} \mathrm{O}_{3}$ to assess the role of support in $\mathrm{MgO}$ catalyst activity. The liquid yields varied from 30 to $54 \mathrm{wt} \%$ based on the experimental conditions. For the noncatalytic pyrolysis experiment, the highest liquid yield was $54 \mathrm{wt} \%$ at $500{ }^{\circ} \mathrm{C}$. The results revealed that adding $\mathrm{MgO} \mathrm{MgO} / \mathrm{Al}_{2} \mathrm{O}_{3}$, and $\mathrm{MgO} / \mathrm{AC}$ declines the liquid yield and increases the gas yield. The catalysts exhibited significant deoxygenation activity, which enhances the quality of the pyrolysis oil and increases the heating value of the bio-oil. Of the catalysts that had high deoxygenation activity, $\mathrm{MgO} / \mathrm{AC}$ had the highest relative yield. The loading of $\mathrm{MgO} / \mathrm{AC}$ varied from 5 to $30 \mathrm{wt} \%$ of feed to the pyrolysis reactor. As the catalyst load increases, the liquid yield declines, while the gas and char yields increase.

Copyright (C) 2021 by Authors, Published by BCREC Group. This is an open access article under the CC BY-SA License (https://creativecommons.org/licenses/by-sa/4.0).

Keywords: Municipal Solid Waste; Pyrolysis; Bio-oil; Catalytic Pyrolysis; Waste Management

How to Cite: H. Almohamadi, A. Aljabri, E.R.I. Mahmoud, S.Z. Khan, M.S. Aljohani, R. Shamsuddin (2021). Catalytic Pyrolysis of Municipal Solid Waste: Effects of Pyrolysis Parameters. Bulletin of Chemical Reaction Engineering \& Catalysis, 16(2), 342-352 (doi:10.9767/bcrec.16.2.10499.342-352)

Permalink/DOI: https://doi.org/10.9767/bcrec.16.2.10499.342-352

\section{Introduction}

Today, municipal solid waste (MSW) production has been enhanced by the increase in population and the demand by citizens for luxury lifestyles [1,2]. More than 2 billion tons of MSW

* Corresponding Author.

Email: hha@iu.edu.sa (H. Almohamadi) are produced annually, and $218 \mathrm{~kg}$ of MSW are produced per person [3], which affects the environment because MSW occupies land, contaminates the soil and groundwater, and produces undesirable gases [4]. Additionally, MSW has been treated using several methods, such as landfilling, recycling, and burning. The common and oldest method to treat MSW is landfilling, 
which buries the waste in the ground [5]. However, landfilling has long-term effects on human health by contaminating underground water via the emission of gases and organics [6]. Furthermore, the incineration method has been investigated to produce energy from MSW through combustion [2,7]. This method could minimize the accumulation of MSW in the ground; however, it significantly influences the environment by increasing greenhouse gas emissions. The environmental effects of this method are significant obstacles in this process [7].

Treating MSW by burning or dumping in landfills creates environmental and health issues that encourage governments and researchers to search for alternatives and convert MSW into useful products. The MSW is a biomass source containing an average of $30-34 \mathrm{wt} \%$ food, 18-22 wt\% paper, 16-20 wt\% plastic, 8$12 \%$ glass, $8-12$ wt $\%$ metals, and $4-8$ wt $\%$ agriculture waste [8]. Moreover, $50 \%$ to $60 \%$ of MSW (paper, glass, plastic, and metals) could be recycled, and $30 \%$ to $50 \%$ of MSW could be converted to fuel and energy [9]. In the last two decades, thermochemical treatments of MSW to produce oil and chemical have been a tremendous and interesting challenge for researchers and technologists [10-12]. One of the thermochemical treatment methods is pyrolysis, which converts MSW into liquid fuel, gases, and char $[2,10-12]$. The gases that contain light hydrocarbon and CO can be used for energy and heat production. The char could be used as a fertilizer or carbon material or be burned to produce heat and energy for the pyrolysis reactor [13]. Furthermore, it is an environmentally friendly process due to fewer emissions than gasification $[14,15]$.

Several factors, such as: the pyrolysis temperature and catalysts, have a significant impact on the product yields of MSW pyrolysis $[16,17]$. The primary product is pyrolysis oil $[18,19]$. Ersan Pütün [20] examined the impact of the temperature on the yield of biomass pyrolysis products. He found that, as the temperature increased from 400 to $550{ }^{\circ} \mathrm{C}$, the bio-oil yield improved from 40 to $45 \mathrm{wt} \%$ and the char yield declined from 35 to 24 wt\%. He stated that the optimum temperature for biomass pyrolysis was $550{ }^{\circ} \mathrm{C}$, because the bio-oil yield declines and gas yield increases at higher temperatures [20]. His results were supported by the findings by Miandad et al. [21], who conducted a pyrolysis experiment for plastic waste using a batch reactor, and the reaction temperature varied from 400 to $500{ }^{\circ} \mathrm{C}$ [21]. The char yield declined as the reaction temperature increased.
They reported that the optimum temperature for pyrolyzing plastic waste is $450{ }^{\circ} \mathrm{C}$ [21].

Using pyrolysis oil as fuel for vehicles is a significant outlet [22,23]. Production from MSW content, water, and oxygenated organics leads to a decrease in the oil's heating value [23]. Furthermore, the high oxygen content in the bio-oil decreases its thermal stability. Thus, it can not be used directly as fuel for vehicles. Upgrading the pyrolysis oil using hydrotreatment or hydrodeoxygenation methods enhances oil stability and increases the heating value $[24,25]$. However, the hydrotreatment process requires high pressure, high temperature, and catalysts, making the process very expensive and complicated [13]. Catalytic pyrolysis of MSW could upgrade the quality of bio-oil.

In catalytic pyrolysis of MSW, serval catalysts have been investigated and examined, such as zeolites, metal oxides, and metal hydroxide [2]. Different catalysts exhibit specific catalytic activity. For example, dolomite is inexpensive but has a limited lifetime at higher temperatures $\left(>500{ }^{\circ} \mathrm{C}\right)[26]$. Synthesized metal oxides are expensive materials and have a quick deactivation rate. Zeolites have highly active catalytic pyrolysis, but the oil yield is meager due to high coke formation. Bimetallics are expensive catalysts and exhibit high catalytic activity, but the coking formation is very high [26]. Zeolite catalysts have been investigated for catalytic pyrolysis of MSW or biomass [27]. Y-zeolite, $\beta$-zeolite, and HZSM- 5 catalysts have been examined for catalytic pyrolysis owing to their high surface area and acidity [12]. These catalysts produce oil with a high yield of aromatics and coke due to their higher acidity, increasing the coke formation rate [28]. Ates et al. [12] studied the impact of adding Y-zeolite, B-zeolite, and HZSM-5 catalysts to a batch reactor pyrolysis of MSW at $500{ }^{\circ} \mathrm{C}$. The feedstock contained paper, plastic, organic waste, and textile, and $50 \mathrm{~g}$ of MSW was placed in the reactor. The reaction time was set up to be in the range of 72 to $85 \mathrm{~min}$ [12]. The results indicated that Yzeolite produced a lower char yield (48 wt\%) and a higher gas yield because Y-zeolite's high surface area enhanced the contact between the feedstock and catalysts and increased the cracking reaction rate [12]. Moreover, the pyrolysis oil yield and quality could be improved by the zeolite catalysts, as observed by Gandidi et al. [29]. They used zeolite catalysts to pyrolyze MSW, including biomass, rubber, paper, textile, and plastic. A fixed-bed vacuum reactor was applied to pyrolyze particles of MSW of 5 
to $10 \mathrm{~cm}$. The feedstock-to-catalyst ratio was 2 , and the reaction time was $60 \mathrm{~min}$ [29]. Adding the catalysts to the reactor increased the liquid yield from 15 to $48 \mathrm{wt} \%$ and the gas yield from 21 to $50 \mathrm{wt} \%$ [29].

Metal oxide catalysts have been widely used for the pyrolysis of MSW [2,12,30,31]. Some, such as $\mathrm{V}_{2} \mathrm{O}_{5}$ and $\mathrm{MnO}_{2}$, are precious and cannot be synthesized easily on a large scale. However, some of them, such as $\mathrm{Al}_{2} \mathrm{O}_{3}$ and $\mathrm{CaO}$, are inexpensive and could be synthesized on a large scale. Li et al. [31] studied the impact of reaction temperature and $\mathrm{Al}_{2} \mathrm{O}_{3}$ catalysts on the product yields of MSW catalytic pyrolysis [31]. The pyrolysis oil yield increased from 12 to $45 \mathrm{wt} \%$ as the reaction temperature increased from 350 to $500{ }^{\circ} \mathrm{C}$. However, the pyrolysis oil yield declined to $26 \mathrm{wt} \%$ when the temperature increased to $540{ }^{\circ} \mathrm{C}$ because the cracking and coking reactions increased at a high temperature $\left(500{ }^{\circ} \mathrm{C}\right)$ [31]. Adding $\mathrm{Al}_{2} \mathrm{O}_{3}$ increased the carbon and hydrogen content in the pyrolysis oil, improving the higher heating value (HHV) of the pyrolysis oil [31]. Furthermore, $\mathrm{MgO}$ catalysts have been used in the catalytic pyrolysis of MSW, because adding $\mathrm{MgO}$ to a pyrolysis reactor improves the deoxygenation rate and the oil quality, as reported by Fang et al. [32]. The MSW included food, wood, paper, and plastic [32]. The catalyst load was $5 \mathrm{wt} \%$ of the feedstock. The presence of $\mathrm{MgO}$ improved the yield of aromatic compounds and declined the yield of oxygen-containing compounds because the $\mathrm{MgO}$ catalyst enhanced deoxygenation [32]. Moreover, Ryu et al. [33] investigated the pyrolysis of lignin in the presence of $\mathrm{MgO}$ or active carbon (AC) and $\mathrm{MgO} / \mathrm{Al}_{2} \mathrm{O}_{3}$. They found that $\mathrm{MgO} / \mathrm{Al}_{2} \mathrm{O}_{3}$ enhanced the bio-oil quality compared to noncatalytic pyrolysis because $\mathrm{MgO} / \mathrm{Al}_{2} \mathrm{O}_{3}$ increased the cracking rate [33]. Additionally, $\mathrm{MgO} / \mathrm{AC}$ increased the aromatic compound yield compared to $\mathrm{MgO} / \mathrm{Al}_{2} \mathrm{O}_{3}$ because the high surface area of the support enhanced the deoxygenation rate [33].

From the literature results and findings, a stable, inexpensive, and active catalyst for the catalytic pyrolysis of MSW is still under investigation. Thus, this study evaluates the impact of pyrolysis parameters on the yield of MSW

Table 1. MSW contents.

\begin{tabular}{lc}
\hline Composition of MSW & $\mathrm{Wt}(\%)$ \\
\hline Food & 42.4 \\
Agriculture & 9.5 \\
Paper & 15.9 \\
Plastic & 32.2 \\
\hline
\end{tabular}

pyrolysis products. The reaction temperature, catalyst loading, and catalyst support were evaluated. In addition, $\mathrm{MgO}$ supported $\mathrm{AC}$ and $\mathrm{Al}_{2} \mathrm{O}_{3}$ to evaluate the support role of $\mathrm{MgO}$ catalyst activity.

\section{Materials and Methods}

\subsection{Materials}

The materials of $\mathrm{Mg}\left(\mathrm{NO}_{3}\right)_{2} 6 \mathrm{H}_{2} \mathrm{O}$ (SigmaAldrich, 99\%), commercial $\gamma-\mathrm{Al}_{2} \mathrm{O}_{3}$ (Sasol North America, 99\%), and Darco AC (Sigma-Aldrich, $100 \%$ ) were used for preparing the catalysts ( $\mathrm{MgO}, \mathrm{Al}_{2} \mathrm{O}_{3}, \mathrm{AC}, \mathrm{MgO} / \mathrm{Al}_{2} \mathrm{O}_{3}$, and $\mathrm{MgO} / \mathrm{AC}$ ). $\mathrm{A}$ mix of MSW was used as the feedstock for the pyrolysis reactor, and Table 1 presents the MSW content. Table 2 presents the ultimate analysis and HHV of MSW, which is determined by using the following formula [34]:

$$
\begin{aligned}
H H V \operatorname{dry}(\mathrm{MJ} / \mathrm{kg})= & 0.3491 C+1.1783 H+0.1005 S \\
& -0.1034 O-0.015 N-0.0211 A
\end{aligned}
$$

where $\mathrm{C}, \mathrm{H}, \mathrm{S}, \mathrm{O}, \mathrm{N}$, and $\mathrm{A}$ represent mass percentages on a dry basis of carbon, hydrogen, sulfur, oxygen, nitrogen, and ash, respectively, for the contents in feedstock.

\subsection{Catalyst Preparation}

An aqueous solution prepared from $0.1 \mathrm{~N}$ $\mathrm{HNO}_{3}$ and $\mathrm{Mg}\left(\mathrm{NO}_{3}\right)_{2} .6 \mathrm{H}_{2} \mathrm{O}$ (Sigma-Aldrich) was used to prepare $\mathrm{MgO}$. The precipitate was stirred for $4 \mathrm{~h}$ at $70{ }^{\circ} \mathrm{C}$. Then, it was filtered and dried at $115{ }^{\circ} \mathrm{C}$ for $18 \mathrm{~h}$. Then, the $\mathrm{MgO}$ catalyst was calcined at $500{ }^{\circ} \mathrm{C}$ for $5 \mathrm{~h}$. Commercial $\gamma-\mathrm{Al}_{2} \mathrm{O}_{3}$ (Sasol North America) was crushed and sieved to attain a $\gamma-\mathrm{Al}_{2} \mathrm{O}_{3}$ powder, which was dried at $115^{\circ} \mathrm{C}$ for $18 \mathrm{~h}$. Then, it was calcined at $500{ }^{\circ} \mathrm{C}$ for $4 \mathrm{~h}$. Next, $\gamma-\mathrm{Al}_{2} \mathrm{O}_{3}$

Table 2. Ultimate and proximate analyses of MSW.

\begin{tabular}{cc}
\hline \multicolumn{2}{c}{ Ultimate Analysis } \\
\hline Elements & (dry basis) MSW (wt\%) \\
\hline $\mathrm{C}$ & 47.31 \\
$\mathrm{H}$ & 6.28 \\
$\mathrm{O}$ & 38.42 \\
$\mathrm{~S}$ & 0.17 \\
$\mathrm{~N}$ & 0.98 \\
\hline \multicolumn{2}{c}{ Proximate Analyses } \\
\hline Volatile & 77.94 \\
Fixed carbon & 15.22 \\
Ash & 6.84 \\
HHV (Mj/kg) & 19.8 \\
\hline
\end{tabular}


was co-impregnated with an aqueous solution prepared from $0.1 \mathrm{~N} \mathrm{HNO}_{3}$ and $\mathrm{Mg}\left(\mathrm{NO}_{3}\right)_{2} .6 \mathrm{H}_{2} \mathrm{O}$ (Sigma-Aldrich) using the incipient wetness impregnation method to prepare $\mathrm{MgO} / \mathrm{Al}_{2} \mathrm{O}_{3}$. Then, the catalysts were dried at $115{ }^{\circ} \mathrm{C}$ for 18 $\mathrm{h}$ and calcined at $450{ }^{\circ} \mathrm{C}$ for $5 \mathrm{~h}$. The $\mathrm{AC}$ catalysts were prepared using Darco AC (SigmaAldrich), which was crushed, dried at $115{ }^{\circ} \mathrm{C}$ for $18 \mathrm{~h}$, and calcined at $500{ }^{\circ} \mathrm{C}$ for $6 \mathrm{~h}$. Finally, the $\mathrm{MgO} / \mathrm{AC}$ catalyst was prepared using the same method of $\mathrm{MgO} / \mathrm{Al}_{2} \mathrm{O}_{3}$.

\subsection{Catalyst Characterization}

The catalysts' texture properties, such as: Brunauer-Emmett-Teller (BET) surface area, pore-volume, and average pore size, were determined using $\mathrm{N}_{2}$ adsorption-desorption isotherms calculated at $77 \mathrm{~K}$ using a Micromeritics ASAP 2020 analyzer [3]. The samples were dried at $115^{\circ} \mathrm{C}$ under a vacuum for $6 \mathrm{~h}$ prior to the analysis. Crystalline phases in the catalysts were identified using X-ray diffraction (XRD). A Bruker D8 Focus (LynxEye detector) with Co-Ka1 radiation $(\lambda=1.79 \AA)$ was used to collect the XRD catalyst patterns. The step size was 0.05 , and the time step was $0.8 \mathrm{~s}$ [3].

\subsection{Thermogravimetric Analysis}

A Mettler Toledo TGA (SDTA851) was used to conduct the thermogravimetric analysis (TGA) of MSW to assess the optimum reaction temperature. The analysis was performed by heating $2 \mathrm{mg}$ of MSW from 30 to $800{ }^{\circ} \mathrm{C}$ at the

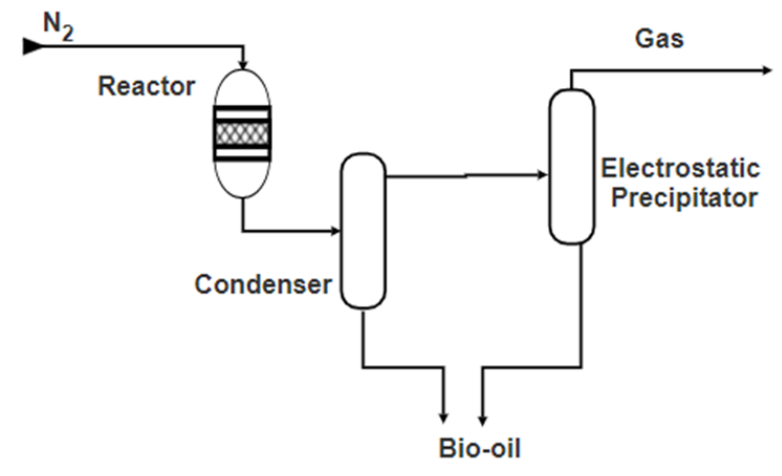

Figure 1. Pyrolysis process schematic. heating rate of $10{ }^{\circ} \mathrm{C}$ per min under $\mathrm{N}_{2}$ flow of $40 \mathrm{~mL} / \mathrm{min}$ [21].

\subsection{Pyrolysis of Municipal Solid Waste}

Figure 1 presents the pyrolysis process schematic, where MSW with an average particle size of $2 \mathrm{~mm}$ was used as feedstock for the pyrolysis reactor. Moreover, $200 \mathrm{~g}$ of biomass was placed in a fixed-bed reactor operated in batch mode. The pyrolysis reactor was made up of 40 stainless steel with $4 \mathrm{~cm}$ i.d. and $24 \mathrm{~cm}$ in length. The pyrolysis reactor was heated from $30{ }^{\circ} \mathrm{C}$ to the set temperature at a heating rate of $10^{\circ} \mathrm{C} / \mathrm{min}$. Four thermocouples were placed inside the reactor to monitor the reaction temperature. The reaction temperature, residence time, catalyst loading, and type of catalyst were varied to investigate the impact of pyrolysis parameters on the product's yields. The MSW was converted into organic vapor and gas. A preheater $\mathrm{N}_{2}$ was employed to carry reaction products (vapor and gas) toward a condenser. Pyrolysis oil was collected from the condenser and the electrostatic precipitator and was analyzed using a Thermo Scientific Flash 2000 elemental analyzer to quantify the element content. Oxygen content in the liquid was obtained by subtracting the $\mathrm{C}, \mathrm{H}$, and $\mathrm{N}$ from the total mass. The oil was analyzed using a Hewlett-Packard HP 7890 Q2010 gas chromatograph-mass spectrometer (GC-MS) to analyze the oil composition. Analyzing the oil using GC-MS was explained in detail by [21] The residence time of the reaction was counted from the first bio-oil drop into the condenser. After the experiment was conducted, the pyrolysis reactor was cooled to $25^{\circ} \mathrm{C}$. Then, the char yield was collected and calculated by subtracting the catalyst weight. The mass values of the bio-oil and char were measured, and the gas was calculated by subtracting the bio-oil and char yields from the total feed.

\section{Results and Discussions}

The textural properties of the catalysts are presented in Table 3. From the results, AC had the highest BET surface area and pore volume,

Table 3. Textural properties of the catalysts.

\begin{tabular}{lccc}
\hline & $\mathrm{MgO}$ content $(\mathrm{wt} \%)$ & BET Surface Area $\left(\mathrm{m}^{2} / \mathrm{g}\right)$ & Pore volume $\left(\mathrm{cm}^{3} / \mathrm{g}\right)$ \\
\hline $\mathrm{MgO}$ & 100 & 22 & 0.073 \\
$\gamma-\mathrm{Al}_{2} \mathrm{O}_{3}$ & 0 & 176 & 0.34 \\
$\mathrm{AC}$ & 0 & 547 & 0.78 \\
$\mathrm{MgO} / \gamma-\mathrm{Al}_{2} \mathrm{O}_{3}$ & 40 & 68.64 & 0.19 \\
$\mathrm{MgO} / \mathrm{AC}$ & 40 & 131.28 & 0.47 \\
\hline
\end{tabular}


followed by $\gamma-\mathrm{Al}_{2} \mathrm{O}_{3}, \mathrm{MgO} / \mathrm{AC}, \mathrm{MgO} / \gamma-\mathrm{Al}_{2} \mathrm{O}_{3}$, and $\mathrm{MgO}$, respectively. The BET surface area of $\mathrm{MgO}$ is $22 \mathrm{~m}^{2} / \mathrm{g}$. The AC BET surface area declined from 547 to $131 \mathrm{~m}^{2} / \mathrm{g}$ after adding $\mathrm{MgO}$ (40 wt\%). The BET results suggest that adding $\mathrm{MgO}$ to $\mathrm{AC}$ and $\gamma-\mathrm{Al}_{2} \mathrm{O}_{3}$ decreased the support porosity because the pores of $\mathrm{AC}$ and $\gamma-\mathrm{Al}_{2} \mathrm{O}_{3}$ were filled with $\mathrm{MgO}$. These results agree with those in the literature [35]. Penkova et al. [35] informed that the BET surface area of $\mathrm{MgO} / \gamma-\mathrm{Al}_{2} \mathrm{O}_{3}$ declined from 137 to $65 \mathrm{~m}^{2} / \mathrm{g}$ when the $\mathrm{MgO}$ loading increased from 5 to $30 \mathrm{wt} \%$, suggesting that the $\mathrm{MgO}$ aggregation rate increased with an increase in the loading of $\mathrm{MgO}$ [36]. Moreover, Cimino et al. [36] reported that increasing $\mathrm{MgO}$ loading from 10 to $30 \mathrm{wt} \%$ decreased the BET surface area of $\mathrm{MgO} / \mathrm{AC}$ catalysts from 576 to $403 \mathrm{~m}^{2} / \mathrm{g}$, because the aggregation rate increased. This study and the literature indicate that adding $\mathrm{MgO}$ decreased the support porosity due to the aggregation of $\mathrm{MgO}$ particles, and the pores of the support were filled with $\mathrm{MgO}$.

All catalysts were characterized using XRD to determine the crystalline phase. The XRD patterns of the catalysts are illustrated in Figure 2 . The peaks (at $2 \theta \cong 42.92^{\circ}, 62.25^{\circ}$, and $77.82^{\circ}$ ) are very sharp for pure $\mathrm{MgO}$, suggesting the crystallites are very large [36]. The XRD patterns for $\gamma-\mathrm{Al}_{2} \mathrm{O}_{3}$ demonstrated that the peaks appeared at $2 \theta \cong 37.53^{\circ}, 45.68^{\circ}$, and $66.69^{\circ}$. As depicted in Figure 2, no peak exists for $\mathrm{AC}$, suggesting that $\mathrm{AC}$ is mostly amorphous. Adding $\mathrm{MgO}$ to $\gamma-\mathrm{Al}_{2} \mathrm{O}_{3}$ shifted the peaks of $\gamma-\mathrm{Al}_{2} \mathrm{O}_{3}$ and $\mathrm{MgO}$ to a lower angle due to the metal-metal interaction between $\mathrm{MgO}$ and $\gamma-\mathrm{Al}_{2} \mathrm{O}_{3}$ [35]. Also, the formation of a magnesium-defective spinel might cause the shift to lower angles [35]. Penkova et al. [35] reported

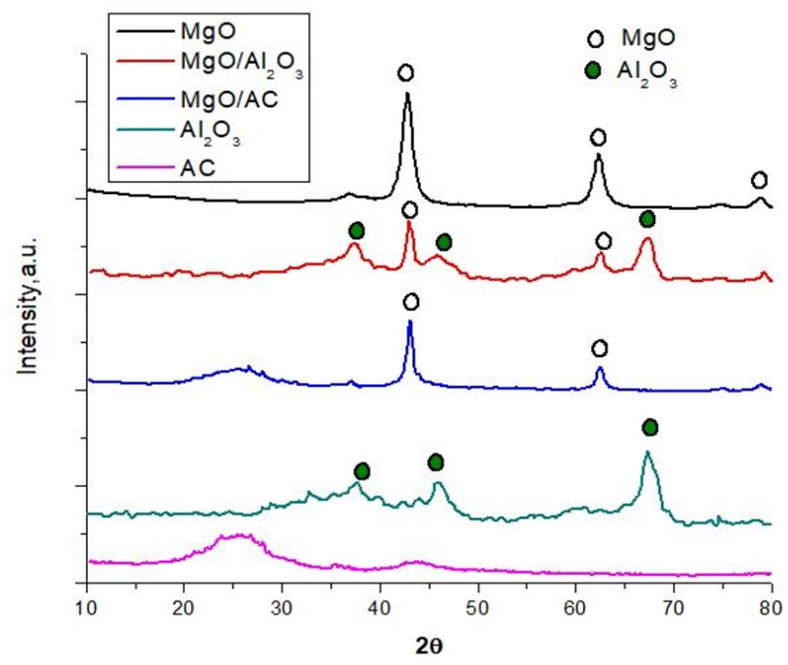

Figure 2. XRD patterns of the catalysts. increasing the loading of $\mathrm{MgO}$ on $\gamma-\mathrm{Al}_{2} \mathrm{O}_{3}$ from 10 to $30 \mathrm{wt} \%$, shifting the peaks of $\gamma-\mathrm{Al}_{2} \mathrm{O}_{3}$ from $\left(2 \theta \cong 37.19^{\circ}, 45.30^{\circ}\right.$, and $\left.65.87^{\circ}\right)$ to lower angles $\left(2 \theta \cong 36.89^{\circ}, 45.00^{\circ}\right.$, and $\left.65.57^{\circ}\right)$ due to the formation of the $\mathrm{MgAl}_{2} \mathrm{O}_{3}$ spinel layer. Despite the high BET surface area of AC, the XRD patterns of $\mathrm{MgO} / \mathrm{AC}$ confirmed the presence of $\mathrm{MgO}$, and the peaks were very sharp, reflecting that $\mathrm{MgO}$ presents as a large cluster on AC. These results agree with those in the literature [36]. Cimino et al. [36] reported that the intensity of $\mathrm{MgO}$ peaks and crystallite size increased with an increasing $\mathrm{MgO}$ load from 10 to $30 \mathrm{wt} \%$ for $\mathrm{MgO} / \mathrm{AC}$ catalysts. In contrast, Zhang et al. [37] found that the $\mathrm{MgO}$ peak intensity was very low for $20 \mathrm{wt} \% \mathrm{MgO} / \mathrm{AC}$ owing to the high surface area of AC. For $\mathrm{MgO} / \mathrm{Al}_{2} \mathrm{O}_{3}$ and $\mathrm{MgO} / \mathrm{AC}$ catalysts, the $\mathrm{MgO}$ peaks are very sharp due to the high loading of $\mathrm{MgO}$ (40 $\mathrm{wt} \%)$. The XRD results indicate that $\mathrm{MgO}$ is present in the catalyst surface, even though the support has a high surface area.

The TGA results illustrate that MSW decomposition started at $300{ }^{\circ} \mathrm{C}$ and reached $71 \%$ decomposition at $500{ }^{\circ} \mathrm{C}$, as displayed in Figure 3 . Increasing the temperature from 500 to 600 ${ }^{\circ} \mathrm{C}$ improved the decomposition by just $6 \%$. Thermal decay of MSW occurred in three stages. The first one occurred at $\left(200-310^{\circ} \mathrm{C}\right)$ and broke the substantial bonds into smaller bonds. Around $6 \%$ of MSW decays at this stage. The second stage occurred at $\left(310-500{ }^{\circ} \mathrm{C}\right)$ and broke the small bonds into hot volatiles and gases. The decomposition of MSW at this stage is $65 \%$. The final stage occurred $\left(500-800{ }^{\circ} \mathrm{C}\right)$, which converts the volatiles into gases. The decomposition of MSW at this stage is $9 \%$. The TGA results confirm the optimum temperature to convert the MSW to bio-oil, which is $500{ }^{\circ} \mathrm{C}$

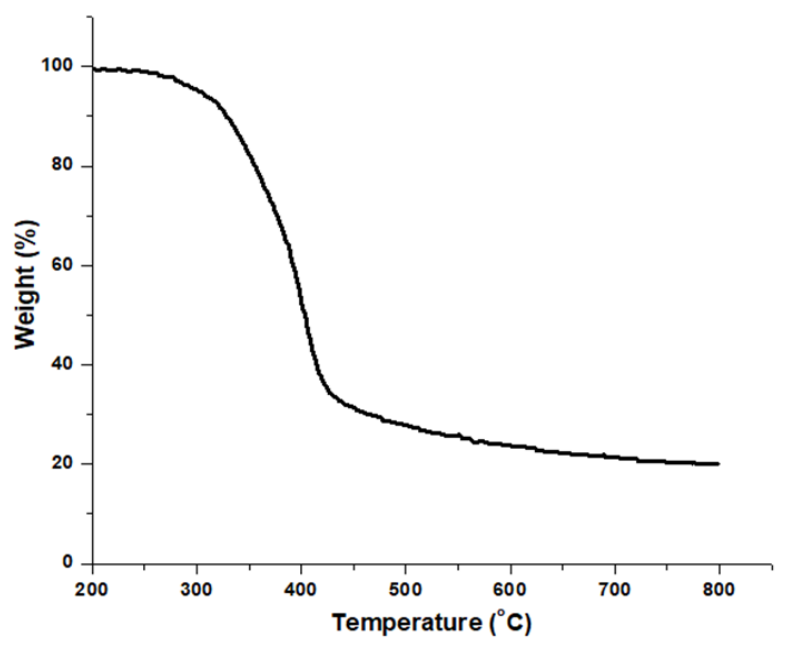

Figure 3. TGA analysis of MSW. 
because more than $71 \%$ decomposition was attained at $500{ }^{\circ} \mathrm{C}$, which consents with the results informed by Buah et al. [38]. They reported that the heating rate had not had a significant impact on the decomposition of MSW and that MSW started to decompose at $350{ }^{\circ} \mathrm{C}$, reaching the maximum decomposition at 500 ${ }^{\circ} \mathrm{C}$ [38]. They stated that the ideal temperature for MSW pyrolysis is around $500{ }^{\circ} \mathrm{C}$ [38]. The TGA results demonstrate that the ideal temperature for MSW pyrolysis is $500^{\circ} \mathrm{C}$.

The reaction temperature was varied from 400 to $600{ }^{\circ} \mathrm{C}$. As presented in Figure 4, for the noncatalytic pyrolysis experiment, as the reaction temperature increased, the gas yield improved, and char yield declined. The maximum liquid yield was $54 \mathrm{wt} \%$ at $500{ }^{\circ} \mathrm{C}$. At $400{ }^{\circ} \mathrm{C}$, the char yield was the highest (32 wt\%) and decreased until reaching 18 wt\% at $600{ }^{\circ} \mathrm{C}$. In contrast, the gas yield increased from 17 to 29 wt $\%$ when the reaction temperature increased from 400 to $600{ }^{\circ} \mathrm{C}$. The liquid yield increased with temperature until reaching the highest yield of $54 \mathrm{wt} \%$ at $500{ }^{\circ} \mathrm{C}$. Then, the yield started to decline until reaching $48 \mathrm{wt} \%$ at $600{ }^{\circ} \mathrm{C}$. The liquid yield declined with increased temperature because the cracking reaction rate increased with the temperature, leading to an increased gas yield and declined liquid yield, as explained by Lopez et al. [39]. They investigated the pyrolysis of plastic waste and found the cracking rate increased with temperature [39], and Miandad et al. [21] confirmed this phenomenon. Moreover, Buah et al. [38] examined the impact of the temperature on the bio-oil yield from MSW pyrolysis. They found that increasing the reaction temperature declined char yield and increased the gas yield, which agrees with the results of this study [38]. Additionally,

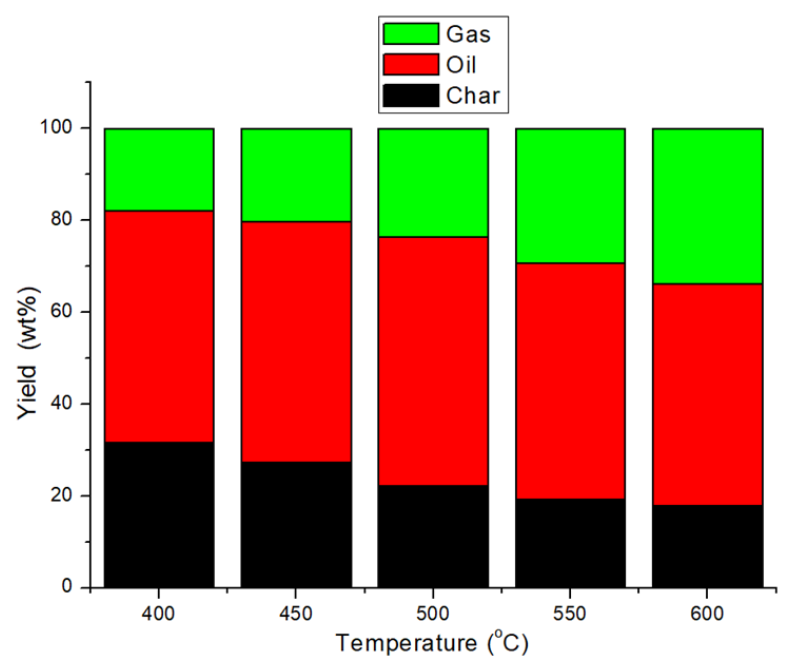

Figure 4. The effect of the temperature on the products yields. the feedstock type has a major impact on the yield of bio-oil. For instance, Horne and Williams [40] found the maximum bio-oil yield at $550{ }^{\circ} \mathrm{C}$ for biomass pyrolysis, which is higher than the optimum temperature found for this study. Also, pyrolysis MSW at low temperature $\left(<550^{\circ} \mathrm{C}\right)$ is preferred to save energy and cost. These TGA and pyrolysis results demonstrate that the ideal temperature for pyrolysis of MSW is $500{ }^{\circ} \mathrm{C}$.

The residence time effect on the product yield was investigated to obtain the optimum resistance time for pyrolysis. As illustrated in Figure 5, as the reaction time increased from 20 to $60 \mathrm{~min}$, the char yield declined, and the gas yield increased. When the reaction time increased from 20 to $40 \mathrm{~min}$, the liquid yield improved from 52 to $54 \mathrm{wt} \%$, which is insignificant. The 40-min resistance time produced the highest liquid yield of $54 \mathrm{wt} \%$. Similar outcomes were informed by Miandad et al. [21] and Lopez et al. [39]. Miandad et al. [21] examined the impact of reaction time on plastic waste pyrolysis product yield. The time varied from 60 to $120 \mathrm{~min}$. The char yield declined from $9 \mathrm{wt} \%$ to $5 \mathrm{wt} \%$, and the gas yield improved with an increase in the reaction time [21]. However, the reaction time did not have a major impact on the oil yield. The type of feedstock and reactor dimension influence the residence time of MSW pyrolysis, as informed by Jung et al. [17]. From the results of the presented study, the reaction time significantly influences the liquid yield and a minor effect on the char and gas yields.

Figure 6 and Table 4 present the impact of adding catalysts to the pyrolysis of MSW. For noncatalytic pyrolysis, the bio-oil contented 35 wt\% of oxygen, and the HHV was $25 \mathrm{MJ} / \mathrm{kg}$.

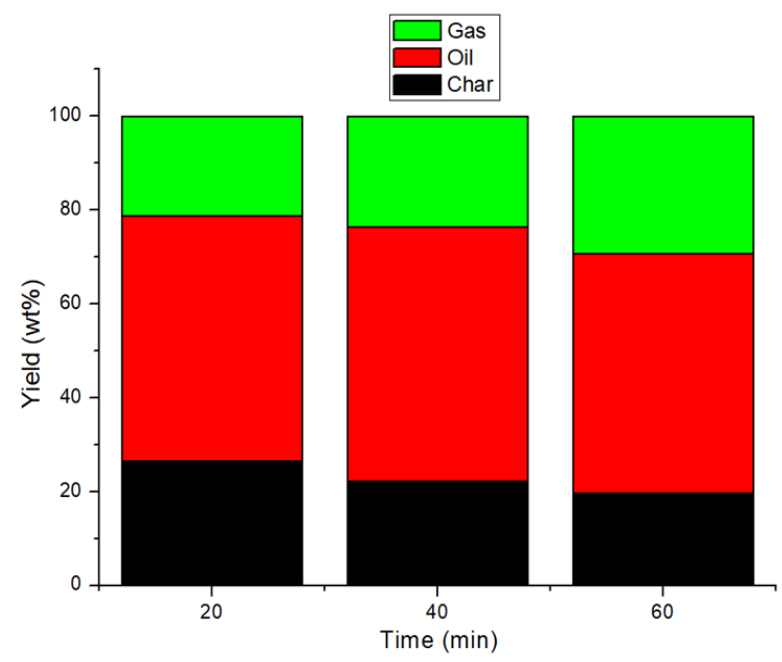

Figure 5. The effect of residence time on the products yields. 
The high oxygen content in the bio-oil decreased the oil quality, making the oil upgrade stage more complicated, as reported by Case $e t$ al. [41]. They conducted a pyrolysis experiment on pine sawdust at $500{ }^{\circ} \mathrm{C}$ and found that the oxygen content in the bio-oil was more than 26 wt\%. They stated that, as the oxygen content increased in the bio-oil, the bio-oil viscosity increased, which requires two steps to upgrade the bio-oil: stabilization and hydrotreatment [41]. For the catalytic pyrolysis, the catalyst load was $20 \mathrm{wt} \%$ of the feed. Adding pure $\mathrm{MgO}$ to the pyrolysis reactor increased the gas yield by $4 \%$ and decreased the bio-oil yield by $5 \%$. Adding $\mathrm{MgO}$ improved the bio-oil quality by enhancing the deoxygenation rate, decreasing the oxygen content and oxygen-to-carbon ratio. This result agrees with that of Fang et al. [32] who investigated the impact of adding $\mathrm{MgO}$ to the reactor pyrolysis of MSW.

Adding $\mathrm{MgO}$ decreased the bio-oil yield and improved the gas yield because it decreased the activation energy for the reaction from 300 to $160 \mathrm{~kJ} / \mathrm{mol}$ and increased the cracking rate [32]. Adding $\mathrm{MgO}$ increases the deoxygenation rate, decreasing the oxygen-to-carbon ratio of the bio-oil [32]. The char yield improved from 22 to $28 \mathrm{wt} \%$, and the bio-oil yield declined from 54 to $47 \mathrm{wt} \%$ by adding $\mathrm{MgO} / \mathrm{Al}_{2} \mathrm{O}_{3}$ to the

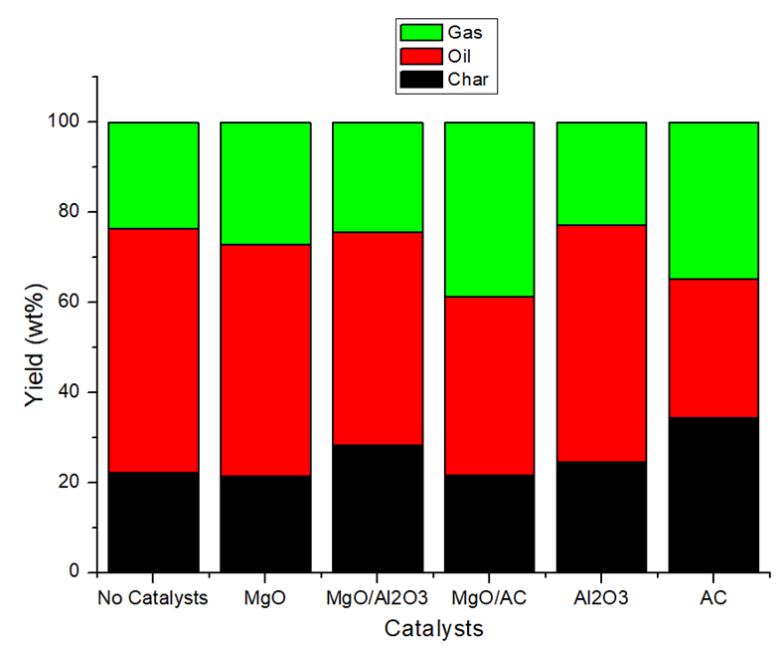

Figure 6. The effect of the catalysts on the products yields. reactor. However, adding $\mathrm{MgO} / \mathrm{Al}_{2} \mathrm{O}_{3}$ enhances the bio-oil quality because the $\mathrm{MgO}$ deposit on $\mathrm{Al}_{2} \mathrm{O}_{3}$ has a high surface area, increasing the reaction rate by increasing the contact between the catalysts and feedstock $[27,42]$.

Adding $\mathrm{MgO} / \mathrm{Al}_{2} \mathrm{O}_{3}$ improved the $\mathrm{HHV}$ of the bio-oil from 25 to $29 \mathrm{MJ} / \mathrm{kg}$. The char yields increased because the coking rate increased from adding the catalysts [27,43,44]. Adding $\mathrm{MgO} / \mathrm{AC}$ increased the gas yield from 24 to 39 $\mathrm{wt} \%$ and declined the bio-oil yield from 54 to $40 \mathrm{wt} \%$. The high surface area of $\mathrm{MgO} / \mathrm{AC}$ increases the cracking rate, enhancing the bio-oil quality by decreasing the oxygen-to-carbon ratio and increasing the hydrogen-to-carbon ratio.

Adding pure $\mathrm{Al}_{2} \mathrm{O}_{3}$ does not significantly impact the reaction product's yields. However, adding $\mathrm{Al}_{2} \mathrm{O}_{3}$ enhances the bio-oil quality by decreasing the bio-oil oxygen content from 35 to $30 \mathrm{wt} \%$. Li et al. [31] examined the role of adding $\mathrm{Al}_{2} \mathrm{O}_{3}$ to the pyrolysis of MSW. They found that the bio-oil yield (45 wt\%) was attained at $500{ }^{\circ} \mathrm{C}$, which is higher than the biooil yield attained in this study. They also found the $\mathrm{Al}_{2} \mathrm{O}_{3}$ improved the bio-oil quality by increasing the aromatic hydrocarbon content [31]. The difference between these results is because the reaction conditions and the MSW type are different. In contrast, adding pure AC decreased the bio-oil from 54 to $31 \mathrm{wt} \%$ and improved the gas yield by $10 \mathrm{wt} \%$ and the char yield by $12 \mathrm{wt} \%$ due to adding AC, enhancing the cracking and coking reactions [27,44]. Pure $\mathrm{AC}$ decreases the oxygen-to-carbon ratio because $\mathrm{AC}$ enhances the decarboxylation rate $[27,32]$. The high char amount is owning to the large pore size of AC, as reported by [20,33]. Based on the balance between the quality and yield of bio-oil in Figure 6 and Table 4, $\mathrm{MgO} / \mathrm{AC}$ is the best catalyst to produce bio-oil from MSW because of the high surface area of the support and the $\mathrm{MgO}$ activity for deoxygenation. Furthermore, adding the $\mathrm{MgO} / \mathrm{AC}$ catalysts improved the HHV of the bio-oil from 25 to $33 \mathrm{MJ} / \mathrm{kg}$. This study demonstrated that adding catalysts $\left(\mathrm{MgO}, \mathrm{MgO} / \mathrm{Al}_{2} \mathrm{O}_{3}, \mathrm{MgO} / \mathrm{AC}\right.$, $\mathrm{Al}_{2} \mathrm{O}_{3}$, and $\mathrm{AC}$ ) to the pyrolysis reactor increas-

Table 4. The bio-oil element analysis.

\begin{tabular}{lcccccc}
\hline & $\mathrm{C} \%$ & $\mathrm{H} \%$ & $\mathrm{O} \%$ & $\mathrm{O}: \mathrm{C}$ & $\mathrm{H}: \mathrm{C}$ & $\mathrm{HHV}(\mathrm{MJ} / \mathrm{kg})$ \\
\hline No Catalysts & 58.4 & 6.7 & 34.9 & 0.45 & 1.38 & 25 \\
$\mathrm{MgO}$ & 64.7 & 6.9 & 28.4 & 0.33 & 1.28 & 28 \\
$\mathrm{MgO} / \mathrm{Al}_{2} \mathrm{O}_{3}$ & 67.1 & 7.1 & 25.8 & 0.29 & 1.27 & 29 \\
$\mathrm{MgO} / \mathrm{AC}_{\mathrm{Al}} \mathrm{O}_{3}$ & 75.2 & 7.3 & 17.5 & 0.17 & 1.16 & 33 \\
$\mathrm{AC}$ & 62.5 & 6.6 & 30.9 & 0.37 & 1.27 & 26 \\
\hline
\end{tabular}


es the gas and char yields, declines the bio-oil yield, and improves the bio-oil quality.

Catalyst loading was investigated to determine the optimum load of $\mathrm{MgO} / \mathrm{AC}$, and the results are presented in Figure 7. As the catalysts load increased, the bio-oil declined, and the gas yield increased because adding the catalysts increased the cracking rate. When catalyst loading was $30 \mathrm{wt} \%$ of the feed, the char

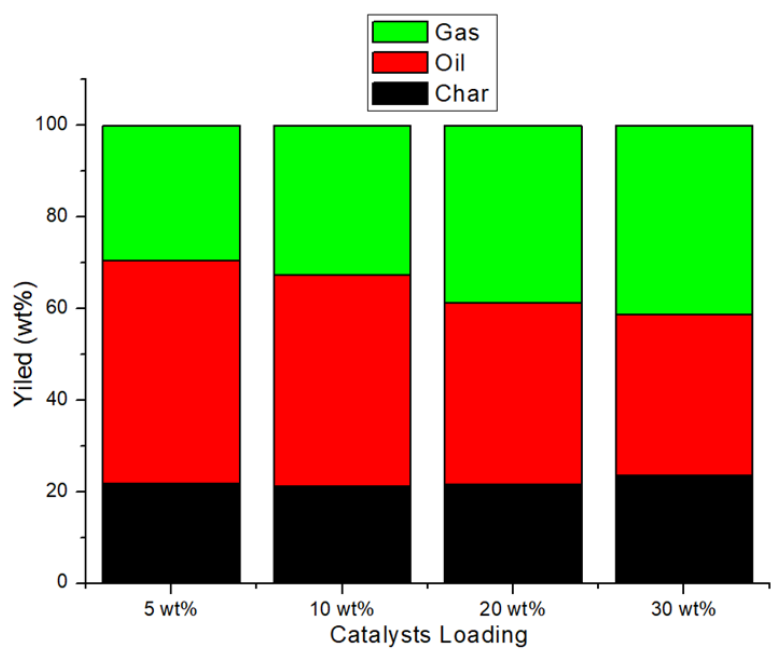

Figure 7. The effect of catalysts loading on the products yields.
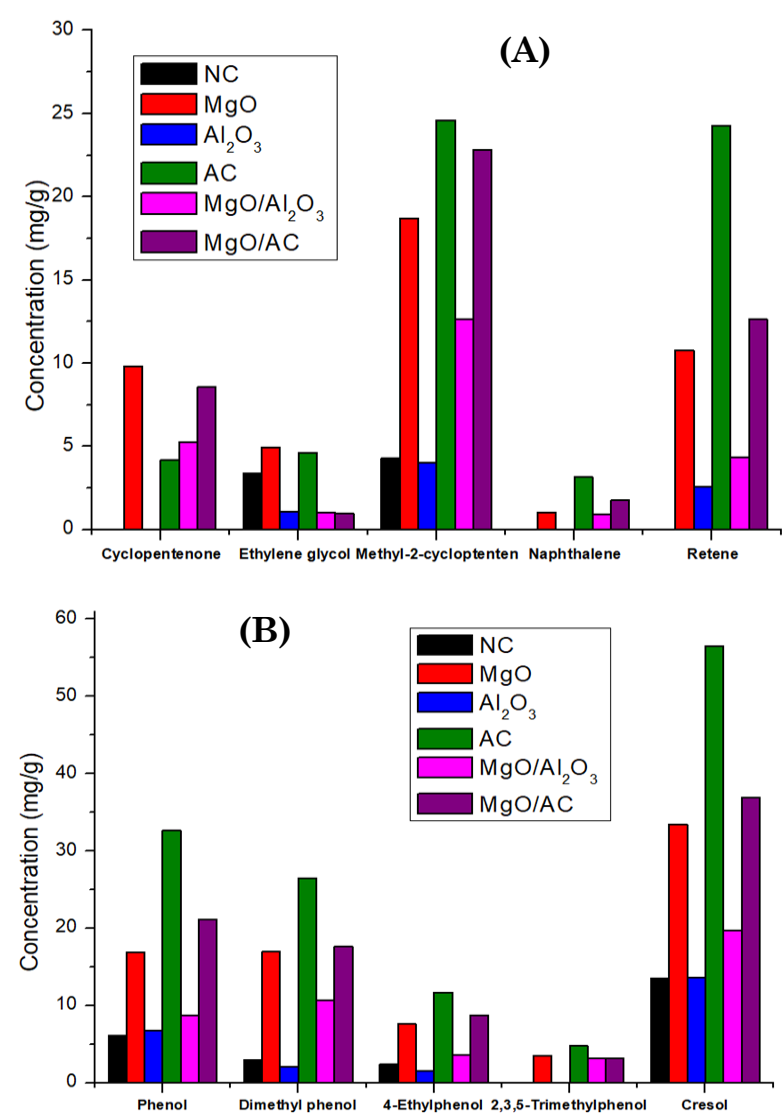

yield increased because increasing the catalyst load leads to an increased coking rate. This result agrees with that of Aysu and Küçük [45], who investigated the impact of catalyst loading on the produced pyrolysis yields. They added $\mathrm{Al}_{2} \mathrm{O}_{3}$ and $\mathrm{ZrO}_{2}$ to the pyrolysis reactor for different loadings [45]. For both catalysts, catalyst loading increased from 5 to $15 \mathrm{wt} \%$ of the feed, the bio-oil yield declined, and the gas yield improved. They stated that adding the catalysts enhances the rate of cracking and decreases the rate of polymerization [45]. Moreover, Garba et al. [22] found the same results for pyrolysis of bagasse using HZSM- 5 at $500{ }^{\circ} \mathrm{C}$. When the catalyst loading increased from 5 to $15 \mathrm{wt} \%$, the liquid yield declined from 50 to $20 \mathrm{wt} \%$, and the gas yield improved from 19 to $48 \mathrm{wt} \%$ [22]. They found that increasing the catalyst loading increases the cracking rate and aromatic bio-oil components [22]. Catalyst loading had no significant influence on the char yield because the coking rate was not enhanced by HZSM-5 [22]. In contrast, Pütün [20] studied the impact of catalyst loading on the product yields of pyrolysis biomass using $\mathrm{MgO}$ catalysts at $550{ }^{\circ} \mathrm{C}$. As catalyst loading increased from 5 to $20 \mathrm{wt} \%$ of the feed, the char yield increased from 20 to $27 \mathrm{wt} \%$, which
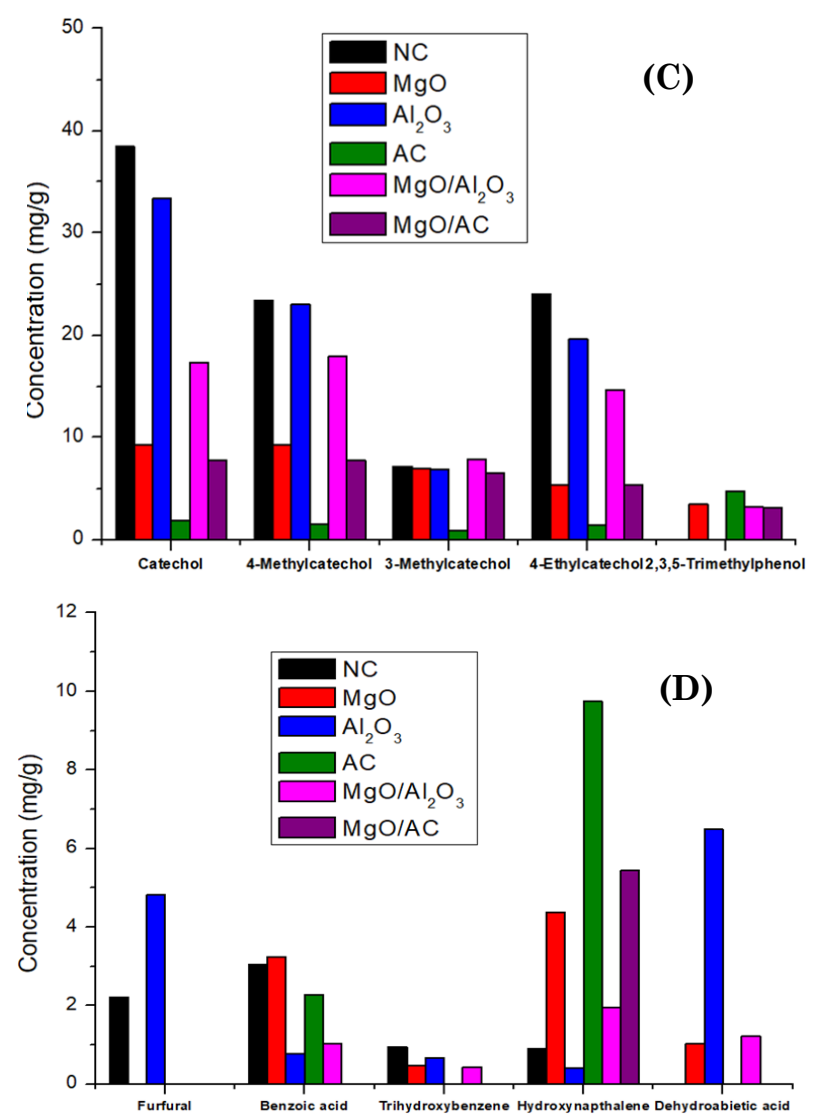

Figure 8. A-D The most significant compounds of bio-oil analyzed by GC-MC. 
agrees with the results of this study [20]. Pütün stated that the increase of the $\mathrm{MgO}$ catalysts enhances the coking rate, which increases the char yield [20]. The results assert that catalyst loading highly influences the liquid and gas yields.

The most significant compounds analyzed by GC-MC are presented in Figure 8 A-D. Furfural is a typical biomass pyrolysis product produced using noncatalytic pyrolysis and $\mathrm{Al}_{2} \mathrm{O}_{3}$, as depicted in Figure $8 \mathrm{D}$. When $\mathrm{MgO}$, $\mathrm{MgO} / \mathrm{Al}_{2} \mathrm{O}_{3}, \mathrm{MgO} / \mathrm{AC}$, and $\mathrm{AC}$ catalysts were added to the pyrolysis reactor, the furfural dispersed, and the cyclopentene and naphthalene concentrations increased. As illustrated in Figure $8 \mathrm{~A}$, adding $\mathrm{MgO}$ and $\mathrm{MgO} / \mathrm{AC}$ catalysts increases the formation of cyclopentene and $\mathrm{Me}$ thyl-2-cyclopentene due to the increased cracking rate caused by adding the catalysts [32]. These results are in agreement with those found by Case et al. [41], finding that adding $\mathrm{CaO}$ as catalysts to the pyrolysis of pine sawdust decreases the furfural formation and enhances the formation of cyclopentenones [41]. Another remarkable result is that AC catalysts increased the retene yield in the bio-oil because $\mathrm{AC}$ has a high surface area that promotes the cracking rate over the carboxylation rate $[9,10]$. Figure $8 \mathrm{~B}$ illustrated that $\mathrm{MgO}, \mathrm{MgO} / \mathrm{AC}$, and $\mathrm{AC}$ exhibit higher selectivity to phenols, indicating that acid compounds could be converted into phenols. Figure $8 \mathrm{C}$ reveals that these catalysts $(\mathrm{MgO}, \mathrm{MgO} / \mathrm{AC}$, and $\mathrm{AC})$ present lower selectivity to catechols because they can be converted into aromatic hydrocarbons through demethoxylation reactions. This result agrees with that by Ryu et al. [33], who reported that adding $\mathrm{MgO} / \mathrm{AC}$ to the pyrolysis of lignin increases the aromatic hydrocarbon yield because $\mathrm{MgO}$ catalysts enhance the dihydroxylation rate and demethoxylation reactions [33]. Figure $8 \mathrm{D}$ demonstrates that $\mathrm{MgO} / \mathrm{AC}$ catalysts decrease the selectivity of the reaction to benzoic acid because $\mathrm{MgO}$ enhances the deoxygenation reaction and increases the deoxygenated aromatic compounds, as displayed in Figure 8A. Therefore, adding $\mathrm{MgO} / \mathrm{Al}_{2} \mathrm{O}_{3}$ and $\mathrm{MgO} / \mathrm{AC}$ increases the aromatic compound yield and improves the bio-oil quality.

\section{Conclusions}

The TGA results illustrate that MSW decomposition starts at $300{ }^{\circ} \mathrm{C}$, reaching about $71 \%$ decomposition at $500{ }^{\circ} \mathrm{C}$. The $40 \mathrm{~min}$ resistance time produces the highest liquid yield at $54 \mathrm{wt} \%$. The liquid yields varied from $30 \%$ to $54 \%$ based on the experimental conditions. For the noncatalytic pyrolysis experiment, as the temperature increases, the gas yield increases, and char yield decreases. The maximum liquid yield was $54 \%$ at $500{ }^{\circ} \mathrm{C}$. The results indicated that adding $\mathrm{MgO}, \mathrm{MgO} / \mathrm{Al}_{2} \mathrm{O}_{3}$, and $\mathrm{MgO} / \mathrm{AC}$ declines the oil yield and increases the gas yield. However, the catalysts exhibited significant deoxygenation activity, which enhances the quality of the oil. Of the catalysts that had high deoxygenation activity, $\mathrm{MgO} / \mathrm{AC}$ had the highest relative yield. The loading of $\mathrm{MgO} / \mathrm{AC}$ varied from 5 to $30 \mathrm{wt} \%$ of feed to the pyrolysis reactor. As catalyst loading increases, the liquid yield decreases, while the gas and char yields increase. The $\mathrm{MgO} / \mathrm{AC}$ catalyst showed high activity, improved the oil's quality, and is inexpensive.

\section{Acknowledgements}

The authors would like to thank the Scientific Research Deanship, the Islamic University of Madinah, for the support provided, with Tamayyuz 2 grant number 585.

\section{References}

[1] Kumar, A., Samadder, S.R. (2017). A review on technological options of waste to energy for effective management of municipal solid waste. Waste Management, 69, 407-422, doi: 10.1016/j.wasman.2017.08.046

[2] Li, Q., Faramarzi, A., Zhang, S., Wang, Y., Hu, X., Gholizadeh, M. (2020). Progress in catalytic pyrolysis of municipal solid waste. Energy Conversion and Management, 226, 113525, doi: 10.1016/j.enconman.2020.113525

[3] Almohamadi, H., Smith, K.J. (2020). Beneficial effect of adding $\mathrm{AlOOH}$ to the $\mathrm{Al}_{2} \mathrm{O}_{3}$ washcoat of a $\mathrm{PdO}$ catalyst for methane oxidation. The Canadian Journal of Chemical Engineering, 98, 281-293, doi: 10.1002/cjce.23605

[4] Wang, W., Gao, X., Li, T., Cheng, S., Yang, H., Qiao, Y. (2018). Stabilization of heavy metals in fly ashes from municipal solid waste incineration via wet milling. Fuel, 216, 153-159, doi: 10.1016/j.fuel.2017.11.045

[5] Bosmans, A., Vanderreydt, I., Geysen, D., Helsen, L. (2013). The crucial role of Wasteto-Energy technologies in enhanced landfill mining: a technology review. Journal of Cleaner Production, 55, 10-23, doi: 10.1016/j.jclepro.2012.05.032

[6] Cheng, S., Qiao, Y., Huang, J., Wang, W., Yu, Y., Xu, M. (2019). Effects of $\mathrm{Ca}$ and $\mathrm{Na}$ acetates on nitrogen transformation during sewage sludge pyrolysis. Proceedings of the Combustion Institute, 37, 2715-2722, doi: 10.1016/j.proci.2018.08.018 
[7] Peng, Y., Chen, J., Lu, S., Huang, J., Zhang, M., Buekens, A., Li, X., Yan, J. (2016). Chlorophenols in municipal solid waste incineration: a review. Chemical Engineering Journal, 292, 398-414, doi: 10.1016/j.cej.2016.01.102

[8] Onel, O., Niziolek, A.M., Hasan, M.F., Floudas, C.A. (2014). Municipal solid waste to liquid transportation fuels-Part I: Mathematical modeling of a municipal solid waste gasifier. Computers \& Chemical Engineering, $71, \quad 636-647, \quad$ d o i : 10.1016/j.compchemeng.2014.03.008

[9] Sipra, A.T., Gao, N., Sarwar, H. (2018). Municipal solid waste (MSW) pyrolysis for biofuel production: A review of effects of MSW components and catalysts. Fuel Processing Technology, 175, 131-147, doi: 10.1016/j.fuproc.2018.02.012

[10] Luo, S., Xiao, B., Hu, Z., Liu, S., Guan, Y., Cai, L. (2010). Influence of particle size on pyrolysis and gasification performance of municipal solid waste in a fixed bed reactor. Bioresource Technology, 101, 6517-6520, doi: 10.1016/j.biortech.2010.03.060

[11] Thamavithya, M., Dutta, A. (2008). An investigation of MSW gasification in a spout-fluid bed reactor. Fuel Processing Technology, 89, 949-957, doi: 10.1016/j.fuproc.2008.03.003

[12] Ateş, F., Miskolczi, N., Borsodi, N. (2013). Comparision of real waste (MSW and MPW) pyrolysis in batch reactor over different catalysts. Part I: Product yields, gas and pyrolysis oil properties. Bioresource Technology, 133, 443-454, doi: 10.1016/j.biortech.2013.01.112

[13] AlMohamadi, H., Gunukula, S., DeSisto, W.J., Wheeler, M.C. (2018). Formate-assisted pyrolysis of biomass: an economic and modeling analysis. Biofuels, Bioproducts and Biorefining, 12, 45-55, doi: 10.1002/bbb.1827

[14] Sharuddin, S.D.A., Abnisa, F., Daud, W.M.A.W., Aroua, M.K. (2016). A review on pyrolysis of plastic wastes. Energy conversion and management, 115, 308-326, doi: 10.1016/j.enconman.2016.02.037

[15] Nizami, A., Rehan, M., Ouda, O.K., Shahzad, K., Sadef, Y., Iqbal, T., Ismail, I.M. (2015). An argument for developing waste-to-energy technologies in Saudi Arabia. Chemical Engineering Transactions, 45, 337-342, doi: 10.3303/CET1545057

[16] Seth, D., Sarkar, A. (2004). Thermal pyrolysis of polypropylene: effect of reflux-condenser on the molecular weight distribution of products. Chemical Engineering Science, 59, 24332445, doi: 10.1016/j.ces.2004.03.008

[17] Jung, S., Kim, S., Kim, J. (2013). The influence of reaction parameters on characteristics of pyrolysis oils from waste high impact polystyrene and acrylonitrile-butadiene-styrene using a fluidized bed reactor. Fuel Processing Technology, 116, 123-129, doi: 10.1016/j.fuproc.2013.05.004

[18] Islam, M.N., Beg, M.R.A., Islam, M.R. (2005). Pyrolytic oil from fixed bed pyrolysis of municipal solid waste and its characterization. Renewable Energy, 30, 413-420, doi: 10.1016/j.renene.2004.05.002

[19] Sørum, L., Grønli, M., Hustad, J. (2001). Pyrolysis characteristics and kinetics of municipal solid wastes. Fuel, 80, 1217-1227, doi: 10.1016/S0016-2361(00)00218-0

[20] Pütün, E. (2010). Catalytic pyrolysis of biomass: Effects of pyrolysis temperature, sweeping gas flow rate and $\mathrm{MgO}$ catalyst. $\mathrm{En}$ ergy, $\quad 35, \quad 2761-2766, \quad \mathrm{~d}$ o i : 10.1016/j.energy.2010.02.024

[21] Miandad, R., Nizami, A., Rehan, M., Barakat, M., Khan, M., Mustafa, A., Ismail, I., Murphy, J. (2016). Influence of temperature and reaction time on the conversion of polystyrene waste to pyrolysis liquid oil. Waste Management, $58, \quad 250-259, \quad \mathrm{~d}$ o i : 10.1016/j.wasman.2016.09.023

[22] Garba, M., Musa, U., Olugbenga, A., Mohammad, Y.S., Yahaya, M., Ibrahim, A. (2018). Catalytic upgrading of bio-oil from bagasse: Thermogravimetric analysis and fixed bed pyrolysis. Beni-Suef University Journal of Basic and Applied Sciences, 7, 776-781, doi: 10.1016/j.bjbas.2018.11.004

[23] Weber, R.S., Olarte, M.V., Wang, H. (2014). Modeling the kinetics of deactivation of catalysts during the upgrading of bio-oil. Energy \& Fuels, 29, 273-277, doi: 10.1021/ef502483t

[24] Li, X., Gunawan, R., Wang, Y., Chaiwat, W., $\mathrm{Hu}$, X., Gholizadeh, M., Mourant, D., Bromly, J., Li, C. (2014). Upgrading of bio-oil into advanced biofuels and chemicals. Part III. Changes in aromatic structure and coke forming propensity during the catalytic hydrotreatment of a fast pyrolysis bio-oil with $\mathrm{Pd} / \mathrm{C}$ catalyst. Fuel, 116, 642-649, doi: 10.1016/j.fuel.2013.08.046

[25] Marcilla, A., Beltrán, M., Navarro, R. (2009). Thermal and catalytic pyrolysis of polyethylene over HZSM5 and HUSY zeolites in a batch reactor under dynamic conditions. $A p$ plied Catalysis B: Environmental, 86, 78-86, doi: 10.1016/j.apcatb.2008.07.026

[26] He, M., Xiao, B., Liu, S., Hu, Z., Guo, X., Luo, S., Yang, F. (2010). Syngas production from pyrolysis of municipal solid waste (MSW) with dolomite as downstream catalysts. Journal of Analytical and Applied Pyrolysis, 87, 181-187, doi: 10.1016/j.jaap.2009.11.005

[27] Rahman, M.M., Liu, R., Cai, J. (2018). Catalytic fast pyrolysis of biomass over zeolites for high quality bio-oil-a review. Fuel Processing 
Technology, $180, \quad 32-46, \quad$ doi: 10.1016/j.fuproc.2018.08.002

[28] Hu, X., Gholizadeh, M. (2019). Biomass pyrolysis: A review of the process development and challenges from initial researches up to the commercialisation stage. Journal of Energy Chemistry, 39, 109-143, doi: 10.1016/j.jechem.2019.01.024

[29] Gandidi, I.M., Susila, M.D., Mustofa, A., Pambudi, N.A. (2018). Thermal-catalytic cracking of real MSW into bio-crude oil. Journal of the Energy Institute, 91, 304-310, doi: 10.1016/j.joei.2016.11.005

[30] Karnjanakom, S., Bayu, A., Xiaoketi, P., Hao, X., Kongparakul, S., Samart, C., Abudula, A., Guan, G. (2016). Selective production of aromatic hydrocarbons from catalytic pyrolysis of biomass over $\mathrm{Cu}$ or $\mathrm{Fe}$ loaded mesoporous rod-like alumina. RSC Advances, 6, 5061850629, doi: 10.1039/C6RA09431G

[31] Li, S., Sanna, A., Andresen, J.M. (2011). Influence of temperature on pyrolysis of recycled organic matter from municipal solid waste using an activated olivine fluidized bed. Fuel Processing Technology, 92, 1776-1782, doi: 10.1016/j.fuproc.2011.04.026

[32] Fang S, Yu Z, Ma X, Lin, Y, Chen, L., Liao, Y. (2018). Analysis of catalytic pyrolysis of municipal solid waste and paper sludge using TG-FTIR, Py-GC/MS and DAEM (distributed activation energy model). Energy, 143, 517532, doi: 10.1016/j.energy.2017.11.038

[33] Ryu, H.W., Lee, H.W., Jae, J., Park, Y. (2019). Catalytic pyrolysis of lignin for the production of aromatic hydrocarbons: Effect of magnesium oxide catalyst. Energy, 179, 669-675, doi: 10.1016/j.energy.2019.05.015

[34] Channiwala, S., Parikh, P. (2002). A unified correlation for estimating HHV of solid, liquid and gaseous fuels. Fuel, 81, 1051-1063, doi: 10.1016/S0016-2361(01)00131-4

[35] Penkova, A., Bobadilla, L., Ivanova, S., Dominguez, M., Romero-Sarria, F., Roger, A., Centeno, M., Odriozola, J.A. (2011). Hydrogen production by methanol steam reforming on $\mathrm{NiSn} / \mathrm{MgO}-\mathrm{Al}_{2} \mathrm{O}_{3}$ catalysts: The role of $\mathrm{MgO}$ addition. Applied Catalysis A: General, 392, 184-191, doi: 10.1016/j.apcata.2010.11.016

[36] Cimino, S., Apuzzo, J., Lisi, L. (2019). MgO dispersed on activated carbon as water tolerant catalyst for the conversion of ethanol into butanol. Applied Sciences, 9, 1371, doi: 10.3390/app9071371
[37] Zhang, X., Lei, H., Zhu, L., Wei, Y., Liu, Y., Yadavalli, G., Yan, D., Wu, J., Chen, S. (2015). Production of renewable jet fuel range alkanes and aromatics via integrated catalytic processes of intact biomass. Fuel, 160, 375385, doi: 10.1016/j.fuel.2015.08.006

[38] Buah, W., Cunliffe, A., Williams, P. (2007). Characterization of products from the pyrolysis of municipal solid waste. Process Safety and Environment Protection, 85, 450-457, doi:10.1205/psep07024

[39] Lopez, A., De Marco, I., Caballero, B, Laresgoiti, M., Adrados, A. (2011). Influence of time and temperature on pyrolysis of plastic wastes in a semi-batch reactor. Chemical Engineering Journal, 173, 62-71, doi: 10.1016/j.cej.2011.07.037

[40] Horne, P.A., Williams, P.T. (1996). Influence of temperature on the products from the flash pyrolysis of biomass. Fuel, 75, 1051-1059, doi: 10.1016/0016-2361(96)00081-6

[41] Case, P.A., Wheeler, M.C., DeSisto, W.J. (2014). Formate assisted pyrolysis of pine sawdust for in-situ oxygen removal and stabilization of bio-oil. Bioresource Technology, $173, \quad 177-184, \quad$ d o i : 10.1016/j.biortech.2014.09.075

[42] Abnisa, F., Wan Daud, W.M.A. (2014). A review on co-pyrolysis of biomass: an optional technique to obtain a high-grade pyrolysis oil. Energy Conversion and Management, 87, 7185, doi: 10.1016/j.enconman.2014.07.007

[43] Park, D., Hwang, E., Kim, J., Choi, J., Kim, Y, Woo, H. (1999). Catalytic degradation of polyethylene over solid acid catalysts. Polymer Degradation and Stability, 65, 193-198, doi: 10.1016/S0141-3910(99)00004-x

[44] Elliott, D.C., Hart, T.R., Neuenschwander, G.G., Rotness, L.J., Zacher, A.H. (2009). Catalytic hydroprocessing of biomass fast pyrolysis bio-oil to produce hydrocarbon products. Environmental Progress \& Sustainable Energy: An Official Publication of the American Institute of Chemical Engineers, 28, 441-449, doi: 10.1002/ep.10384

[45] Aysu, T., Küçük, M.M. (2014). Biomass pyrolysis in a fixed-bed reactor: effects of pyrolysis parameters on product yields and characterization of products. Energy, 64, 1002-1025, doi: 10.1016/j.energy.2013.11.053

Selected and Revised Papers from International Conference on Sustainable Energy and Catalysis 2021 (ICSEC 2021) (https://engineering.utm.my/chemicalenergy/icsec2021/) (School of Chemical and Energy Engineering, Faculty of Engineering, Universiti Teknologi Malaysia, 16-17th February 2021) after Peer-reviewed by Scientific Committee of ICSEC 2021 and Peer-Reviewers of Bulletin of Chemical Reaction Engineering \& Catalysis.

Editors (Guest) in this ICSEC 2021 section are Nor Aishah Saidina Amin, Mohd Asmadi Mohammed Yussuf, Salman Raza Naqui, while Editor in Chief is I. Istadi. 